\title{
AMERICANIZATION OF BRAZIL OR A PRAGMATIC WARTIME ALLIANCE? THE POLITICS OF NELSON ROCKFELLER'S OFFICE OF INTER-AMERICAN AFFAIR IN BRAZIL DURING WORLD WAR II
}

\section{AMERICANIZAÇÃO DO BRASIL OU ALIANÇA PRAGMÁTICA EM TEMPOS DE GUERRA? \\ A POLÍTICA DO OFFICE OF INTER-AMERICAN AFFAIRS DE NELSON ROCKFELLER NO BRASIL DURANTE A II GUERRA MUNDIAL}

\author{
AMERICANIZACIÓN DE BRASIL O ALLIANZA PRAGMÁTICA EN \\ TIEMPOS DE GUERRA? \\ LA POLÍTICA DEL OFFICE OF INTER-AMERICAN AFFAIRS DE NELSON \\ ROCKFELLER EN BRASIL DURANTE LA SEGUNDA GUERRA MUNDIAL
}

\section{AMÉRICANISATION DU BRÉSIL OU ENGAGEMENT PRAGMATIQUE EN TEMPS DU GUERRE?}

\section{LA POLITIQUE DE L'OFFICE OF INTER-AMERICAN AFFAIRS DE NELSON ROCKFELLER AU BRÉSIL PENDANT LA SECONDE GUERRE MONDIALE}

DOI: $10.5533 / 1984-2503-20102408$

\section{Ursula Prutsch}

\section{ABSTRACT}

This article considers firstly the wide range of activities spearheaded by the Office of Inter-American Affairs (OIAA) in Brazil and the significance of this wartime institution. The OIAA was created in 1940 and headed by Nelson A. Rockefeller to combat Axis inroads into the South of the Western Hemisphere and deepen U.S. influence in the region. Toward this end it was engaged in a variety of spheres, including finance, commerce, and manufacturing industry, communications and mass media, culture and education. Its politics in Brazil, the most important hemispheric partner moreover, serves to illustrate the intertwining of economy, politics, and culture in United States foreign policy, especially towards Latin America. Secondly, the article will also show 
that the Brazilian government - rather than being a passive recipient of dictums from Washington - worked hard to appropriate the OIAA's agenda to the demands of its own interests in the ongoing nation-building process. In this context the article will ask whether the discourse of brasilidade, the state-controlled construction of a national identity, was a counterweight to the transfer of American Way of Life and of American values to Brazil. Hence, this text will discuss the Brazilian as well as the U.S.-American perspective.

Key-words: United States, Brazil, Office of Inter-American Affairs, americanization, brasilidade.

\section{RESUMO}

Este artigo analisa, em primeiro lugar, a larga gama de atividades promovidas pelo Office of Inter-American Affairs (OIAA) no Brasil e o significado desta instituição de tempos de guerra. O OIAA foi criado em 1940 e liderado por Nelson A. Rockefeller para combater a entrada do Eixo no Sul do continente americano e ampliar a influência dos Estados Unidos na região. Com este intuito, envolveu-se numa série de esferas, como finanças, comércio e indústria, comunicações e mídia de massas, cultura e educação. Sua política no Brasil, seu mais importante parceiro no continente, ilustra, além disso, o entrelaçamento entre economia, política e cultura na política externa dos Estados Unidos, especialmente para a América Latina. Em segundo lugar, o artigo mostrará também que o governo brasileiro - em vez de ser um receptor passivo dos ditames de Washington - trabalhou arduamente para apropriar a pauta do OIAA aos seus próprios interesses no processo em andamento de construção da nação. Neste contexto, o artigo questionará se o discurso de brasilidade, a construção de uma identidade nacional controlada pelo Estado, foi um contrapeso para a transferência do American Way of Life e dos valores americanos ao Brasil. Assim, este texto discutirá tanto a perspectiva brasileira quanto estadounidense.

Palavras-chave: Estados Unidos, Brasil, Office of Inter-American Affairs, americanização, brasilidade.

\section{RESUMEN}

El artículo analiza, en primer lugar, la amplia gama de actividades promovidas por el Office of Inter-American Affairs (OIAA) en Brasil y el significado de esta institución de 
tiempos de guerra. EI OIAA fue creado en 1940 y liderado por Nelson A. Rockefeller para combatir la entrada del Eje en el Sur del continente americano y ampliar el influjo de los Estados Unidos en la región. Con este objetivo, se ha enfrascado en una serie de esferas, como finanzas, comercio e industria, comunicaciones y comunicación de masas, cultura y educación. Su política en Brasil, su más importante aparcero en el continente, ilustra, además, el entrelazamiento entre economía, política y cultura en la política exterior de los Estados Unidos, sobre todo para América Latina. En segundo lugar, el artículo mostrará también que el gobierno brasileño - en lugar de ser un receptor pasivo de los dictámenes de Washington ha trabajado arduamente para apropiar el programa del OIAA a sus propios intereses en el proceso en marcha de construcción de la nación. En este contexto, el artículo cuestionará si el discurso de brasilidade, la construcción de una identidad nacional controlada por el Estado, fue un contrapeso para la transferencia del American Way of Life y de los valores americanos al Brasil. De este modo, el texto discutirá tanto la perspectiva brasileña como la estadounidense.

Palabras-clave: Estados Unidos, Brasil, Office of Inter-American Affairs, americanización, brasilidade.

\section{RESUMÉ}

Cet article examine en premier lieu le large spectre d'activités promues par l'Office of Inter-American Affairs (OIAA) au Brésil et le rôle de cette institution des temps de guerre. L'OIAA a été crée en 1940, avec à sa tête Nelson A. Rockefeller, pour combattre l'entrée de l'Axe sur le continent américain et amplifier l'influence des États-Unis d'Amérique dans la région. À cet effet, l'OIAA s'est immiscé dans toute une série de sphères, telles que les finances, le commerce et l'industrie, les communications et les médias de masse, la culture et l'éducation. Sa politique au Brésil, son partenaire le plus important sur le continent, illustre en outre les liens entre les aspects économiques, politiques et culturels au sein de la politique d'affaires étrangères menée par les Etats-Unis d'Amérique, spécialement en ce qui concerne l'Amérique Latine. En deuxième lieu, l'article montrera également que le gouvernement brésilien - au lieu de se comporter comme récepteur passif des prescriptions de Washington - a beaucoup travaillé pour rendre l'ordre du jour de l'OIAA approprié à ses propres intérêts, en vue de corroborer le processus en cours de construction de la nation. En fonction de ce contexte, l'article analysera la 
capacité du discours de la "brasilité", entendu sous la perspective de la construction d'une identité nationale contrôlée par l'État, à faire contrepoids au transfert de l'American Way of Life et des valeurs américaines au Brésil. Par conséquent, ce texte s'intéressera aussi bien à la perspective brésilienne qu'à l'optique nord-américaine.

Mots-clés : États-Unis, Brésil, Office of Inter-American Affairs, américanisation, «brasilité ».

Nelson Aldrich Rockefeller's first visit to Brazil in September 1942 was of highly symbolic nature for the Brazilian-American relations. The young multimillionaire was not coincidentally present in Rio de Janeiro on exactly September 7, Brazil's national holiday. His family's name was known in the South American state, had it been an important laboratory for U.S.-sponsored public health efforts, exerted especially by the Rockefeller Foundation since the early 1930s, and now it was becoming a key destination for North-South technology transfers. Brazil was a huge potential market for U.S. products and the source of several important commodities found in factories and kitchen pantries across the United States. For American industrial and commercial interests, Brazil represented a seemingly inexhaustible supply of raw materials and foodstuffs. After a long period of neutrality, the Brazilian government had declared war on Germany and Italy, joining the United States and the Allied cause in August 1942.

Rockefeller's trip to Rio de Janeiro was intended to further the agenda of expanding U.S. influence in South America, but it was also complimented by the goals of the nationalistic Estado Novo, or New State, inaugurated by Brazilian president-dictator Getúlio Vargas (1883-1954) in November 1937. The convergence of interests was evident in the 1942 Independence Day festivities, when Nelson Rockefeller stood at Vargas' side and watched more than 30,000 school children under the baton of Heitor Villa Lobos sing in praise of the Brazilian nationalist leader. This propagandistic extravaganza of civic parades, youth, and choral song, was part and parcel of the Vargas regime's effort to parlay international relations into domestic campaigns of security and order. Two days prior to the president's joint appearance with Rockefeller, Vargas had ordered a police raid against suspected Nazi spies, leading to the arrest of more than 3,000 people. The raids coincided with a massive 
media campaign against the country's enemies, real or imagined. The American guest was to be duly impressed by the aggressive anti-axis politics recently adopted by his Brazilian hosts.

Brazilian historians including Luiz Alberto Moniz Bandeira, Gerson Moura and Roberto Gambini ${ }^{1}$, and, more recently, paulista historian Antonio Tota ${ }^{2}$ have put forwarded several arguments about the economic and cultural Americanization of Brazil during the Second World War. Moura's Tio Sam chega ao Brasil (1984) ${ }^{3}$, for example, describes a flood of American consumer products arriving in Brazil as a result of the war alliance with the United States. According to Tota, South America as confronted massive United States economic influence, was undergirded by cultural strategies of domination. They provided important and valuable insights into Brazil's wartime relations with the United States, the earlier studies were influenced by the theory of dependence that interpreted Brazil primarily as a victime of U.S.-influence.

While Gerson Moura's work focus on Brazil's capacity of power play with the United States, Antonio Tota's study of United States influence did not grasp some fundamental dimensions of U.S.-Brazilian relations that need to be addressed in order to understand the workings and impact of U.S. policies directed at Brazil during the war years. When Nelson Rockefeller arrived in Rio in an effort to bring closer together Brazilian and U.S. interests, the Brazilian society was already in the midst of an intense process of nation-building that envisioned certainly changes consistent with, but not led by, United States policy. Not only had the Brazilian government set out to nationalize economic resources and industries as early as 1930, it had embarked on a policy of comprehensive cultural modernization meant to reach into every corner of this vast and diverse country. The histories of social, cultural, and economic change closely associated with Americanization during the interwar and WWII years, then, might be more suitably associated with an autonomous national history.

\footnotetext{
${ }^{1}$ Bandeira, Luiz Alberto Moniz (1973). Presença dos Estado Unidos no Brasil, Rio de Janeiro: Ed. Civilização Brasileira; Moura, Gerson (1982). Brazilian Foreign Relations 1939-1950. The Changing Nature of Brazil-United States Relations during and after the Second World War, Unpublished PhD. Diss., London; Gambini, Roberto (1977). O Duplo Jogo de Getúlio Vargas. Influência Americana e Alemã no Estado Novo, São Paulo: Edições Símbolo.

2 Tota, Antonio Pedro (2000). O Imperialismo Sedutor. A Americanização do Brasil na Época da Segunda Guerra, São Paulo: Companhia das Letras.

${ }^{3}$ Moura, Gerson (1984). Tio Sam chega ao Brasil. A penetração cultural americana, São Paulo: Brasiliense.
} 
This article, indeed, considers firstly the wide range of activities spearheaded by the Office of Inter-American Affairs (OIAA) in Brazil and the significance of this wartime institution. The "Office for Coordination of Commercial and Cultural Relations Between the American Republics" as it was firstly called, was created by order of the Council of National Defense on August 16, 1940 to respond to perceptions of a massive threat to the security of the United States. Its overall purpose may be summarized as follows: it was established to combat Axis inroads into the South of the Western Hemisphere, deepen U.S. influence in the region, and secure the allegiance of Latin America in the upcoming struggle. The Office of InterAmerican Affairs was to facilitate such a thorough mobilization by establishing liaison between various entities of government and between the government and private sectors. Toward this end it engaged, as advisors or members of staff, representative and influential citizens from a variety of spheres, including finance, commerce, and manufacturing industry, communications and mass media, culture and education. Headed by American businessman and philanthropist Nelson A. Rockefeller (19081979), who held the position of the Coordinator of Inter-American Affairs, the OIAA engaged in a vast range of activities, many of which remain to be studied.

Many projects, the OIAA effected, might be understood as politics of "Americanization". Its politics in Brazil, the most important hemispheric partner moreover, serves to illustrate the intertwining of economy, politics, and culture in United States foreign policy, especially towards Latin America. Secondly, the article will also show that the Brazilian government - rather than being a passive recipient of dictums from Washington - worked hard to appropriate the OIAA's agenda to the demands of its own interests in the ongoing nation-building process. In this context the article will ask whether the discourse of brasilidade, the state-controlled construction of a national identity, was counterweight to what the OIAA was intending to instill, namely adherence to the American Way of Life and to American values. Hence, this text will discuss the Brazilian as well as the U.S.-American perspective and the intentions as well as the reactions, strategies of accommodation and resistance of the largest South American state against the U.S.-influence.

\section{Getúlio Vargas' Nation-Building-Project}

Getúlio Vargas had come to power in 1930 in a brief civil war, and he remained in office through various machinations until a bloodless coup removed him from the 
presidential palace in October 1945. As his government set out to transform the vast and heterogeneous society whose political economy was dominated by the interests of the export-oriented agrarian sector into a modern, unified industrial nation-state, Vargas came to be convinced that such a massive undertaking could only succeed under his personal stewardship. With the proclamation of the Estado Novo on November 10, 1937, Vargas asserted the powers of dictatorship to pursue this goal. The Constitution of 1934 was suspended and freedom of the press abolished. With the complete ban on political parties, Vargas relied on the military, the upper class, and the Catholic Church. His regime, moreover, found support in the industrial working class, as it wooed workers with comprehensive social welfare programs into state-regimented unions. Vargas strove toward a peculiar balance of power, not just in his domestic policies, but also in foreign affairs and well into the war years. Whereas some of his ministers sympathized with the fascist regimes in Europe, especially prior to the declaration of belligerence against the Axis, other officials were decided Americanophiles. Of the latter group, standouts included Oswaldo Aranha, Brazil's Ambassador in Washington DC in 1934-7 and later Minister of Foreign Affairs, and Vargas's own daughter Alzira, a close adviser also sympathetic to the Americans ${ }^{4}$.

Like many other countries of the region, Brazil responded to the global economic crisis of the 1930s, which had brought about a steep decline in coffee prices and crisis of foreign exchange and debt, with a set of policies that facilitated import substitution, especially of consumer products and semi-durable manufactures, and greater state control over the nation's economic resources. As the federal government assumed a larger role in the economic and social fabric of the nation, officials fostered strong collective identification with the causes of national recovery. Culture, education, and science also came increasingly into the sphere of federal regulations.

\footnotetext{
${ }^{4}$ For books on Vargas and the Estado Novo see Abreu, Marcelo (1999). O Brasil e a economia mundial 1930-1945, Rio de Janeiro: Civilização Brasileira; Capelato, Maria Helena (1998). Multidões em Cena. Propaganda Política no Varguismo e no Peronismo, São Paulo: Papirus; Dulles, John F.W. (1967). Vargas of Brazil, London, Austin: Texas University Press; Faoro, Raymundo (1977). Os Donos do Poder. Formação do Patronato Político Brasileiro, Porto Alegre: Globo; Hentschke, Jens (1996) Estado Novo. Genesis und Konsolidierung der brasilianischen Diktatur von 1937, Saarbrücken: Verlag für Entwicklungspolitik; see Hentschke, Jens (2006). Vargas and Brazil. New Perspectives, New York: Palgrave, Macmillan, see Carneiro, Maria Luiza Tucci (1999). "O Estado Novo, o Dops e a ideologia da segurança nacional". In: Pandolfi, Dulce (ed.). Repensando o Estado Novo, Rio de Janeiro: Editora FGV, 1999, pp. 327-340; Wirth, John D. (1970). The Politics of Brazilian Development 1930-1945, Stanford, Ca: Stanford University Press; Araujo, Ricardo Benzaquen de (1986). "O Dono da Casa. Notas sobre a imagem do poder no 'mito Vargas'”. In: Religião e Sociedade,13/2, pp. 102-122.
} 
In its effort to form distinct notions of a Brazilian nationhood, the Vargas regime drew upon the modernist movement of the 1920s and other cultural movements framed around an appreciation of the country's distinctive historical roots. Not surprisingly, the conservation and protection of the national heritage became one of the hallmarks of the Vargas government. A progressive monument protection law took effect almost immediately after the declaration of the Estado Novo. In the following five years, the baroque jewels of Minas Gerais and the Jesuit-Guarani mission of São Miguel, in Rio Grande do Sul, among other sites, were restored with state funds ${ }^{5}$.

In spite of these well-publicized efforts, officials in the Vargas regime were periodically perturbed to receive notice that Brazil remained seen as a backward "Nation of Botocudes" in the international concert of nations ${ }^{6}$. Hence, the Press and Propaganda Department (DIP), organized in 1939, assumed strict control over the domestic mass communications systems as well as orchestrated favorable images of the Vargas regime, in particular, and Brazilian civilization, generally. The DIP, in fact, played a central role in the public diplomacy, especially concerning the United States $^{7}$. Indeed, most films, weekly newsreels, and radio programs coming from the States to Brazil had to pass through the DIP's censorship boards before reaching the Brazilian public. And, the DIP distributed various kinds of media about Brazil to U.S. government and media outlets. By closely cooperating with the OIAA, the DIP exerted influence in the way Brazil and its president were presented in the U.S..

The DIP, of course, had to carefully adjust the images it produced to the changing strategic positioning of the Vargas regime. Thus, after mid-1942 and following Brazil's declaration of war on the Axis powers, Vargas, the "Father of the Poor", now also came to be stylized as the most loyal pan-American warrior in the fight against fascism. The Brazilian government represented itself as the "most democratic country of the world [sic]", as foreign minister Oswaldo Aranha wrote to

\footnotetext{
${ }^{5}$ For the founding of universities see Schwartzman, Simon et. al. (1984), Tempos de Capanema, São Paulo: Paz e Terra; for the SPHAN see Williams, Daryle (2001). Culture Wars in Brazil. The First Vargas Regime, 1930-1945, Durham, London: Duke University Press.

6 "O Brasil não pode continuar na situação de uma Botoculandiasinha" in Papers of Gustavo Capanema (Fundação Getúlio Vargas, CPDOC, rolo 17, 626).

${ }^{7}$ See Souza, José Ignacio de Melo (1990). Ação e Imaginario de uma ditadura: Controle, Coerção e Propaganda Política nos Meios de Comunicação durante o Estado Novo, unpublished PhD diss. São Paulo, see Capelato, Maria Helena R. (1998). Op. Cit.; see Goulart, Silvana (1990). Sob a verdade oficial. Ideologia, propaganda e censura no Estado Novo, São Paulo: Marco Zero Editora.
} 
Orson Welles after the actor's intensive filming experiment in Rio de Janeiro ${ }^{8}$. Accordingly, the DIP produced catch phrases to be repeated time and again to underscore this claim, most notably slogans referring to the "two democracies" fighting against the totalitarian regimes in Europe. The irony, of course, was not lost on Brazil's democratic opposition who in turn sought to exploit the wartime coalition in order to undermine the authoritarian grip of the Estado Novo ${ }^{9}$.

As other institutions in the nation-building project, the Press and Propaganda Department employed a number of European immigrants, most of them Jewish refugees ${ }^{10}$. These immigrants in Vargas' service seemed to signal the regime's openness and tolerance, yet they barely masked the fact that at the same time highly restrictive and anti-Semitic immigration laws were severely limiting the number of refugees entering the country. The Estado Novo, moreover, understood how to integrate numerous Brazilian intellectuals into its project. The sociologist Gilberto Freyre, author of Casa Grande e Senzala [1933; Eng. trans: The Masters and the Slaves, (1946)], drafted a central model for the Estado Novo with the myth of the harmonious racial democracy, an important element of its homogenization discourse. Freyre emphasized the integrative abilities of Brazil's nation-state, where European, Asian, and African immigrants lived together harmoniously in a tropical cultural melange. This discourse denied the racism that existed (and exists) in Brazil. It also played a psychologically important role in the country's foreign relations, particularly with regard to the United States. If Brazil was a recipient country for U.S. technology and armaments during World War II and thus clearly the weaker partner in the material transfer, it could on the other hand demonstrate its superiority with respect to racial relations, as the discourse of racial democracy favorably compared Brazil with the apartheid that existed in the U.S. South.

\section{Brazil and the United States: Brothers in War}

As is well known, during World War II the Vargas government came to cooperate with the United States on a broad range of issues. It granted the U.S. the right to establish military bases along the coast of northern Brazil as well as fly-over and air traffic

\footnotetext{
${ }^{8}$ Oswaldo Aranha to Orson Welles, August 13,1942 (NARA II, RG 229, Office of Inter-American Affairs, Records of the Department of Information, Education Division, Box 1261, Folder 2,7).

9 For further details see Prutsch, Ursula (2008). Creating Good Neighbors? Die Kultur- und Wirtschaftspolitik der U.S.A in Lateinamerika, 1940-1946, Stuttgart: Franz Steiner Verlag.

${ }^{10}$ Prutsch, Ursula (2008). Creating Good Neighbors? Die Kultur- und Wirtschaftspolitik der U.S.A in Lateinamerika, 1940-1946, Stuttgart: Franz Steiner Verlag, p. 151.
} 
rights in the Amazon ${ }^{11}$. The Washington Accords, signed in March 1942, granted Brazilian interests exclusive rights to supplying strategic raw materials to the United States, such as rubber, diamonds, mica, iron ore, and tantalite ${ }^{12}$. By 1944, the Vargas regime had sent troops, the Força Expedicionária Brasileira or FEB, to Italy as part of the Fifth Army, The Vargas regime was well aware of the strategic and economic importance of Brazil to the U.S. war effort and knew how to exploit its bargaining position. Hence, Brazil's cooperation came at a price. The U.S. financed the workhorse of Brazil's industrialization, the steel plant Volta Redonda, Rio de Janeiro state ${ }^{13}$. Among those that greatly profited from the wartime alliance was the Brazilian military: lend-lease weaponry and technology transfers from the U.S. helped Brazil to become the leading military power in the region and thus contributed to a marked shift in the balance of power vis-à-vis its main competitor for regional predominance, Argentina.

The growing alliance with the United States, however, did not come about without difficulties and frictions. U.S. war needs directly affected various regions of Brazil. First, U.S. demand for rubber led to a vast increase of economic activity in the huge Amazon basin, a fragile ecosystem that was difficult to exploit and that came to be a test and experimentation area for the Institute of Inter-American Affairs, a branch of the OIAA. Second, coastal cities of the north and northeast, including Belém, Recife, Salvador, and Fortaleza, became home to military airports serving as bridgeheads for U.S. invasion forces heading for Africa and Europe. Thousands of American military personnel were sent to Brazil, and it was reported that

\footnotetext{
${ }^{11}$ Kraus, Louise Theresa (1986). The Establishment of United States Army Air Corps Bases in Brazil, 1938-1945, Unpublished PhD Diss. College Park: University of Maryland; see McCann, Frank D. (1973). The Brazilian-American Alliance 1937-1945, Princeton: Princeton University Press.

${ }^{12}$ For U.S.-Brazilian relations see: McCann, Frank D. (1973). Op. Cit.; Cobbs, Elizabeth Anne (1992) The rich Neighbor Policy. Rockefeller and Kaiser in Brazil, New Haven, London: Yale University Press; see Gambini, Roberto (1977). Op. Cit.; Gellman, Irwin F. (1979) Good Neighbor Diplomacy. United States Policies in Latin America 1933-1945, Baltimore, London: The Johns-Hopkins University Press; Huggins, Martha K. (1989) Political Policing. The United States and Latin America, Durham, London: Duke University Press; Marinho, Maria Gabriela (2001) Norteamericanos no Brasil. Uma história da Fundação Rockefeller na Universidade de São Paulo (1934-1952), São Paulo: Coleção Educação Contemporânea; Bandeira, Luiz Alberto Moniz (1973). Op. Cit.; Moura, Gerson (1982). Brazilian Foreign Relations 1939-1950. The Changing Nature of Brazil-United States Relations during and after the Second World War, Op. Cit.; Miceli, Sergio (1990) A desilusão americana. Relações acadêmicas entre Brasil e Estados Unidos, São Paulo: IDES/Editora Sumaré; Tota, Antonio Pedro (2000). Op. Cit.; Rocha, Denise (1998). "Sportethos und Monumentalismus - Tropischer way of life: die brasilianische Wahrnehmung des NS-Reiches und der U.S.A". In: König, Hans-Joachim and Rinke, Stefan (ed.). Transatlantische Perzeptionen: Lateinamerika-U.S.A-Europa in Geschichte und Gegenwart, Stuttgart: Verlag Hans-Dieter Heinz and Akademischer Verlag, pp. 259-282.

${ }^{13}$ See Veiga, Sandra Mayrink and Fonseca, Isaque (1990). Volta Redonda, entre o aço e os armas, Petrópolis: Editora Vozes; Rady, Donald Edmund (1973). Volta Redonda, Albuquerque, New Mexico: Rio Grande Publishing Company; Wirth, John D. (1970). Op. Cit.
} 
"the excessive number of people from the U.S., investigating, reporting, or arranging for bases, factories, railroads, espionage, propaganda, or movies, concerned the local populace" ${ }^{\text {,14. }}$.

U.S. technicians, who often treated their Brazilian hosts as inferiors, were unaware or outright disrespectful of local cultural codes and thus, hurt local traditions. "They are not subject to control by anyone and there are several instances of drunkenness and furniture smashing, and constant flouting of Brazilian taste such as lack of ties and coats at meals in the best hotels", related two OIAA-informants from Belém do Para to the headquarters in Washington ${ }^{15}$. A military secret service report summarized the ambiance as follows: "The poorer Brazilian classes in the country districts blame the Americanos [sic] for everything and seem to feel the Americans are there to take something away from them rather than help them."16

The wartime alliance also had repercussions in the great urban centers, most notably the metropolis of São Paulo. There, vast new armament industries came into being. While the latter certainly provided new work opportunities, the gearing of Brazil's economy to U.S. war needs at the same time increased scarcity of goods as well as inflationary pressures that soon were felt in daily life. After mid-1943, rationing of fuels, sugar, and milk, forced ordinary Brazilians to queue for the basic necessities of life ${ }^{17}$. Tensions and difficulties such as these were sources of concern for the OIAA's propaganda apparatus that strove to deflect possible criticism of the U.S. and create a general climate of good-will. If overdone, however, such concern for Brazil's goodwill in itself could become a source of irritation, as Foreign Minister Aranha indicated in a much quoted ironic remark: „One more good will mission, and Brazil will declare war on the United States. ${ }^{\text {"18 }}$

\section{Rockefeller's Institute of Inter-American Affairs: The Fight against Fascism, and Business}

The extraction of strategic raw materials such as rubber and the establishment of military bases along the northeastern coastline were among the central interests of

\footnotetext{
${ }^{14}$ Kraus, Louise Theresa (1986). Op. Cit., p. 173.

${ }^{15} \mathrm{~K}$. and T. to Earl Givens, February 6, 1943 (NARA II, RG 229, Office of Inter-American Affairs, Coordination Committee for Brazil, Box 1277, Folder 07,1).

${ }^{16}$ Kraus, Louise Theresa (1986). Op. Cit., p. 169.

${ }^{17}$ Cytrynowicz, Roney (2000). Guerra sem Guerra. A mobilização e o cotidiano em São Paulo durante a Segunda Guerra Mundial, São Paulo: EDUSP.

${ }^{18}$ McCann, Frank D. (1973). Op. Cit., p. 247.
} 
U.S. policy in Brazil. In order to be operationally successful and to minimize frictions, U.S. policies had to overcome a number of logistical challenges. The OIAA stepped in ease tensions. Most notably, the OIAA was charged to help provide foodstuffs and medical care for large contingents of U.S. soldiers and Brazilian workers who were employed either in the giant military construction sites or came to be drawn by the thousands into the Amazon basin as rubber collectors. Drawing on the organizational model and experience of the Rockefeller Foundation, in March 1942, the OIAA established a new agency to handle health and technology projects, the Institute of Inter-American Affairs (IIAA). Its tasks included fighting malaria, the construction of educational institutes for medical personnel and infrastructure improvements. The IIAA's mission partially overlapped with the Vargas government's Marcha para Oeste, which meant to gain access to the economic resources of the Amazon region ${ }^{19}$. The IIAA and the Brazilian government together created the SESP, the Special Service for Healthcare, which established its operative base in Belem do Pará. The main part of the financing was undertaken by Brazil; the U.S. provided loans, know-how and medical supplies. The SESP established hospitals, drained swamps, and administered nearly 18 million atebrine tablets to fight malaria ${ }^{20}$.

Among the target groups the SESP focused upon there were the rubber tappers, known as seringueiros. When Malaysian rubber plantations fell under Japanese control, the United States quickly turned to Brazilian sources, boosting Brazil's rubber production but also requiring a significant reorientation in regional labor markets. The Vargas' government implemented a plan to hiring 50,000 men from the arid areas of the Brazilian northeast to serve as seringueiros. While Brazilian organizations were responsible for the transport and the provisioning of circa 13,000 rubber collectors who were actually transported to the Amazon, Rockefeller's OIAA was given the task of recruiting them. Since the majority of the prospective workers were illiterate, the OIAA chose to approach them through comics. One such widely distributed narratives, for example, told the story of Floriano, a poor Brazilian from the

\footnotetext{
${ }^{19}$ Garfield, Seth (1997). "The Roots of a Plant that Today is Brazil': Indians and the Nation-State under the Brazilian Estado Novo". In: Journal of Latin American Studies 29, p. 748. Report by Ernest E. Maes, June 1942 (NARA II, RG 229, Office of Inter-American Affairs, General Records, Central Files, Group 3, Information, Science and Education, Race, Box 410, Folder U.S.-Section of InterAmerican Institute, TR 47).

${ }^{20}$ For the SESP see Campos, André Luiz Vieira de (1997). International Health Policies in Brazil: The Serviço Especial de Saúde Pública, 1942-1960, Unpublished PhD Diss. The University of Texas at Austin; see Bastos, Nilo Chaves de Brito (1996). SESP-FSESP. Evolução Histórica 1942-1991, Brasilia: Fundação Nacional de Saude.
} 
northeast, who, by collecting latex, was able to secure his existence and marry his fiancée, in addition to fulfilling a task important for the Allied war effort and Brazilian development ${ }^{21}$. OIAA posters adorning restaurants and display windows depicted the battle on the rubber front: "Rub them out with rubber" appears on one of these posters in which an oversized car tire threatens to roll over Hitler, Mussolini, and Hirohito. On another poster a huge octopus with swastika-shaped eyes and large tentacles embracing the globe, is being pierced by an enormous sword; the picture is accompanied by the words "With this weapon we will win".

Safeguarding the food supply for seringueiros in the Amazon and for the military bases was one of the major tasks of the OIAA. Thus, feeding armies of relocated Brazilian workers and thousands of U.S. soldiers stationed in Brazil was feared to develop into a major strain on local food supply with serious effects on agricultural prices. Moreover, the U.S. soldiers found local products to be of low quality, a particular concern that the OIAA tried to resolve by establishing model farms, providing loans to small farmers, organizing agricultural training, and by introducing new hybrid seeds and artificial fertilizers. In order to relieve pressure on the food supply, the OIAA, moreover, sponsored Victory Gardens, turning to one of its favorite didactic methods: sponsoring local competitions. As in other policy areas, the OIAA's Food Supply Division relied on the cooperation by Brazilian agencies, and in 1942, the Brazilian-American Commission of Food Production (CBA) was established. The net effect of such efforts is impossible to gauge with any precision, but it is remarkable that the OIAA at least in one region came under harsh criticism. The OIAA boosted meat and vegetable production in the vicinity of military bases, since Brazilian foodstuff did not meet the quality criteria of U.S. soldiers. As the surplus products were dumped on the local market, they actually decreased prices and provoked local producers to protest ${ }^{22}$.

The networks, built by the OIAA and the Institute of Inter-American Affairs, were extended beyond the war. Once freed from the oversight of the U.S. Congress and the State Department, the American International Association for Economic and

\footnotetext{
21 "Floriano" (NARA II, RG 229, Office of Inter-American Affairs, Coordination Committee for Brazil, Box 1283, Folder Rubber Reserve, Publicity).

${ }_{22}$ Monthly Report, July 16 to August 15, 1944 (NARA II, RG 229, Office of Inter-American Affairs, Coordination Committee for Brazil, Box 1336, Folder Health and Sanitation Newsletters 1943, Folder Food Supply Division, Brazil). See also RAC, RFA, NAR pers. III 4 0, OIAA, Box 4, Brazil 1942-1946, Commercial and financial section. See relatório 17 de agosto, 1942 (Arquivo Itamarati, Consulado em Los Angeles, 48/5/4).
} 
Social Development (AIA) and the International Basic Economy Corporation (IBEC) continued to work in areas of research and commerce ${ }^{23}$.

\section{American Public Diplomacy - The OIAA's Brazilian Division}

Apart from engaging in the logistical needs of the rubber economy and newly established military bases, the OIAA developed a range of other activities that relied upon permanent field offices located throughout the country. After August 1941, the OIAA established subcommittees in São Paulo, Porto Alegre, Florianópolis, Curitiba, Santos, Belo Horizonte, Vitoria, Bahia, Recife, Natal, Fortaleza, Belem and Manaus. All reported to the division office located in Rio. The Brazilian Division and its subcommittees were mainly composed by representatives of large U.S. enterprises, such as General Motors, Kodak, and Goodyear. Until March 1944 the Brazilian Division was run by Berent Friele, a long-time manager of the American Coffee Corporation and after that, by Frank Nattier, special representative to the Coordinator. As a kind of a barometer for local feeling toward America and the Americans, the Brazilian Division and its subcommittees delivered regular feedback to the OIAA's Washington Headquarters. Such feedback served mostly as a guide for the development of informational materials and propaganda contents.

The first of the Brazilian Division's subcommittees came to be established in the fall of 1942 in São Paulo, an important industrial metropolis and port city. As other committees, the São Paulo branch was run by an executive of a large U.S. firm. Arnold Tschudy, a jurist who had completed his doctorate at Berkeley before being hired by Standard Oil California in 1929. Thereafter he had earned an excellent reputation as the head of General Motors Corporation in Brazil. From 1940 onward, he also served as the President of the U.S. Chamber of Commerce in São Paulo. Indeed, Rockefeller's headquarter thought so much of Arnold Tschudy that it disregarded the pay scale for employees of the State Department in order to be able to pay him a salary that was in line with his previous manager's earnings. Tschudy earned more than every other employee of the OIAA with his $\$ 10,200$ salary a year ${ }^{24}$. The importance of São Paulo was also related to the fact that it was home to a sizeable Italian and Japanese minority, a population the OIAA was intent on

\footnotetext{
${ }^{23}$ For documentation see RAC, RFA, NAR pers. III 4, AIA-IBEC.

24 Tschudy received 8,000 dollars a year from the State Department and, despite protests from Secretary of State Cordell Hull, an additional 2,190 dollars from OIAA funds to meet for his living expenses (NARA II, RG 229, Office of Inter-American Affairs, Coordination Committee for Brazil, Box 1328, Folder 31, 5, OIAA São Paulo).
} 
monitoring carefully through its own subcommittee and through other channels. Indeed, the OIAA's research and intelligence branch, the Bureau of Latin American Research, sent an Italo-American informant down to São Paulo, who delivered information for the Washington Office on a regular basis ${ }^{25}$.

Yet, in contrast to the regional setup in Mexico and Argentina, for instance, the Brazilian Division came to be recognized by the Foreign Ministry as an official institution of the U.S. Government ${ }^{26}$, which meant that it was not under the trusteeship of the U.S. Embassy but acted almost independently as a diplomatic authority subject only to supervision from Washington. This peculiar institutional setup allowed for much greater leeway than elsewhere.

During the early stages of its existence, the Brazilian Division assumed comprehensive competencies in economic policies and - what was called "development work"27. Together with the Embassy, it helped to identify firms to be blacklisted and to establish essential Brazilian import needs, from raw materials to spare parts, so as to help Brazil's economy to produce the raw materials and other products urgently needed by the U.S.. The assessment of import requirements and investigations into the ownership of the firms involved was a difficult task, yet it allowed the OIAA to take a deep look into Brazil's economic potential and ownership structures. The areas of competence of the Brazilian Division, however, changed over time as other wartime agencies came to assume various of its functions, particularly in fields related to blacklisting and the requirements of the war economy ${ }^{28}$.

\footnotetext{
${ }^{25}$ Laurence Duggan to ambassador Jefferson Caffery, October 13,1942 (NARA II, RG 84, Rio de Janeiro Embassy, Box 17, Folder 800). Report by Serafino Romualdi, August 11,1942 (NARA II, RG 84, Rio de Janeiro Embassy, Box 7).

${ }^{26}$ See Formation of Regional Coordination Committees (NARA II, RG 229, Office of Inter-American Affairs, Coordination Committee for Brazil, Box 1277, Folder 05.1 (2).

27 "The activities of the Brazilian Division in the commercial and financial field have been adjusted to similar activities of the Coordinator's Office in Washington, with principal emphasis on development work, the purpose of which to aid in strengthening the internal economy of Brazil and in tightening the commercial bonds among the countries of this hemisphere." Commercial and Financial Section (RAC, RFA, NAR pers. III 4 0, OIAA, Box 4, Folder Brazil 1942-1946). The Coordination Committee of the Brazilian Division was headed by Earl C. Givens, manager of General Electric, S.A. Other representatives were: Wingate M. Anderson (Standard Oil Brazil), Harry F. Covington (Cia Expresso Federal), George W. Hufsmith (Light \& Power Co.), Carl Kincaid (lawyer), David L. Lewis (Metro Goldwyn Mayer), C.H. Wiseley (National City Bank of New York), U.G. Keener (Electric Bond \& Share Co.). See RAC, RFA, NAR pers. III 4 0, OIAA, Box 1, Folder 1945, Regional Committees.

${ }_{28}$ The OIAA lost its competence concerning the Black List, which from August 1941 onwards, was defined by the newly created Division of World Trade Intelligence of the State Department. See: NARA II, RG 229, General Records, Central Files, Group 2, Commercial and Financial Economic Developement, Box 108, Folder State Department, Division of World Trade Intelligence.
} 
From late 1942 until 1945, therefore, the Division's main field of action was public diplomacy. The latter had been one of the main assignments since its inception, but the intensity of its propaganda and cultural programs increased markedly during the war. Prior to Pearl Harbor, the Brazilian Division, as Berent Friele recalled in a letter to Rockefeller from August 1943, has had a rocky start. In its propaganda work it relied to a large degree on Spanish-language materials that were also sent to Brazil, causing much criticism. The content in general was so dilettante, that justifiable malice was heaped on the OIAA ${ }^{29}$. After the attack on Pearl Harbor, however, the Division's capabilities had greatly improved. By the time Brazil entered the war, the OIAA had carried out a first massive propaganda push, and until mid1943 the cultural and political relations between the two nations continued to improve.

The Division's public diplomacy campaigns aimed to achieve two major objectives. On the one hand, they were meant to justify the economic and military presence of the U.S. and the wartime alliance in general. On the other hand, they strove to revamp the image of the United States as an idealistic and generous nation with a high standard of education. The OIAA's attempt at image engineering was based on the premise that both the exposure to previous and unfortunate U.S. policies in the real world, most notably to the demeaning experience of the Big Stick in Central America and the Caribbean, as well as to the outpourings of Hollywood's dream factory, had left too negative an impression for Brazilians and Latin Americans in general to be able to appreciate the real nature of the United States. If such exposures had produced images of the U.S. as a predominantly protestant nation driven by capitalistic, materialistic interests, and a society characterized by a promiscuous lifestyle, gangsters, and a generally uncultured population, the OIAA now sought to persuade Latin Americans otherwise.

The Public Diplomacy of the Brazilian Division was multi-faceted: To justify the economic and military presence of the U.S. and the wartime alliance, films, information and propaganda materials produced by the OIAA in Washington or by the local Division again and again captured the sites where natural resources were extracted, where agricultural and healthcare stations had been established. Berent Friele and his team also invited selected groups of well-known Brazilian intellectuals,

\footnotetext{
${ }^{29}$ Berent Friele to Nelson A. Rockefeller, August, 23, 1943 (NARA II, RG 229, Office of Inter-American Affairs, General Records, Central Files, Group 4, Administration, Box 443, Folder Berent Friele).
} 
politicians, and high-ranking civil servants of the DIP for sightseeing tours in the United States. The Brazilian guests were sent on trips that were carefully planned and choreographed by the State Department and that were meant to confront their preconceived and misguided notions of the United States with "reality". For example, these guided tours included New York with its Statue of Liberty, the capital Washington D.C., Detroit as an important industrial center, as well as the Disney studios in Burbank, the worldwide known symbols for U.S.-American film culture.

Scholarships, even more than those fourteen-day-trips for Brazilian VIPs, were deemed especially effective in their capacity to replace misguided preconceptions. Students and professionals educated in the United States were expected to develop into "goodwill ambassadors" on their return home. The Brazilian Division thus maintained a highly active educational and cultural exchange program: it sent Brazilian artists to the North, chose qualified candidates for the newly created InterAmerican Trade Scholarships program, it recruited U.S. technicians to serve in industry and agriculture ${ }^{30}$. and administered rapidly expanding exchange programs for university teachers and students so that they were able to discover the world of "the other". Musicologist Carleton Sprague Smith, who first worked for the OIAA and then for the State Department stressed the importance of cultural exchange and culture politics as part of the U.S. program to enduringly implement American influence on Brazil in a letter to Nelson Rockefeller:

\begin{abstract}
"Along with our countless rubber, naval and military missions we ought to have a Cultural Mission in full swing now which would help to smooth things out after the war when the honeymoon is over. Unless there is a realistic plan to show Democracy at work to our neighbors, they will slip back into the old European patterns. And they cannot be blamed for this because they have never really seen the American intellectual scene, unless they've been to the U.S.,31.
\end{abstract}

While U.S. businessmen were hired by the OIAA to deepen economic relations between the North and the South of the Hemisphere, to help eliminate the economic presence of Axis powers through blacklisting and fill the resulting vacuum, so-called

\footnotetext{
30 Technicians from the U.S. came for the extraction of plant oil, of coal, the breeding of silk caterpillars, cassava production, plant fibers, aluminium, transport, the equipping of hospitals, and mineral prospecting (RAC, RFA, NAR, pers. III 4 0, OIAA, Box 4, Folder Brazil 1942-1946, Commercial and Financial Section).

${ }^{31}$ Carleton Sprague Smith to Nelson Rockefeller, May, 15, 1943 (NARA II, RG 229, General Records, Central Files, group 3, Information, Science and Education, Brazil, Box 418, Folder 1943).
} 
culture ambassadors, like the musicologist Sprague $\mathrm{Smith}^{32}$ and the film director Orson Welles were expected to do the ground-work on the image-front. Their support for the cause, however, often exposed a degree of concern and uneasiness. Smith suggested that communicating democratic values could only be successful through democratic fair play and cooperation. Yet, the war demanded the rapid mobilization of all available resources regardless of whether or not the societies and culture in Latin America were democratically constituted. Therefore, U.S. foreign policy in general, and the OIAA in particular continued to "appease" antidemocratic "elements", and rather looked toward strategies that would explain the burdon of the war effort and downplay its impact on Latin American economies.

\section{Culture policy and culture exchange in mass media and art with the Brazilian Press and Propaganda Department}

Sometimes at odds with the more idealistic cultural ambassadors, the OIAA's businessmen - some of them were friends of Nelson Rockefeller - viewed culture also as a product to be sold and the media and especially films as another market to be conquered by the United States. Films are an artistic-esthetic product, mostly oriented towards mass-consumption. They reflect mentalities, society models and values; films transport political contents and appeal less to rational thinking than to emotional perceptions of audiences ${ }^{33}$. The businesspeople within the OIAA film section particularly looked towards movies as both a mass product to be marketed as well as a vehicle to convey contents, such as the delivery of messages on the American Way of Life, if guided along proper lines. John Hay Whitney, Director of the OIAA film section until June 1942, wrote to Nelson Rockefeller:

"Of the three arms of psychological warfare - radio, news and movies - the latter, from my point of view, has by far the greatest potentialities as it combines the impact of sight and sound. ${ }^{34}$

The Motion Picture Society for the Americas (MPSA), founded in March 1941 in Hollywood, worked as a clearing house for feature and education films, designed

${ }^{32}$ Carleton Sprague Smith first worked for the OIAA; in 1944 he was employed by the State Department to serve as a cultural attaché in São Paulo.

${ }_{33}$ Kirsch, Thomas (1977). Die Entwicklung der argentinischen Filmindustrie, Münster: MAks Publikationen, p. 25; see Mallimacci, Fortunato and Marrone, Irene (1977). Cine e imaginário social, Buenos Aires: Facultad de Ciencias Sociales.

${ }^{34}$ Nelson A. Rockefeller to John Hay Whitney, May 1,1942 (RAC, RFA, NAR pers. III 4 L, Box 263, Folder 2627). In June 1942 Whitney joined the U.S. Air Force and returned to the U.S.A in early 1946. 
mostly for the Latin American market. Its members discussed scripts, included famous Latin Actors in the production, avoided pejorative remarks and cooperated with Will Hay's censorship office, which had engaged Addison Durland, a Cuban American. In the depiction of Latin societies, Durland set value on whiteness and modernity, editing out images of slums, female characters of dubious reputation as well as monologues in broken English ${ }^{35}$. Thus, for the OIAA, "high brow culture" that, like exhibitions and concerts, aimed at more exclusive audiences, was not deemed more important than "low brow" cultural products, such as films.

The Brazilian Press and Propaganda Department DIP was the most important cooperation partner for the OIAA in the field of media and cultural production. Established in 1939 after the Italian propaganda model and influenced by European fascism in terms of aesthetics and staging, the DIP came to be a powerful institution. Once the Vargas regime had decided to align with the United States, the DIP's propaganda division was called upon to legitimize the shift in foreign policy. Although many in the DIP viewed the switch to the "right side" with distrust and halfheartedness, some of its officials had powerful reasons to cooperate with the U.S.. As owners of media production facilities, such as film studios or radio stations, they wanted to profit from the new technology offered by the OIAA.

In August 1941 Walt Disney, together with RKO representative Phil Reisman and John Hay Whitney, director of the OIAA's film division, met DIP director Lourival Fontes in Rio de Janeiro, where they developed strategies of cultural cooperation. The delegates from Hollywood looked for information about the technical standards of Brazilian film studios, about Brazilian tastes and preferences concerning U.S. films and stars, about Brazilian projects and topics for feature and educational films. Above all, they looked for instructions about censureship practices in the South American dictatorship. Disney, Reisman, and Whitney wanted to know whether to avoid concepts like "democracy" or how to put them in the "right context", so that their movies would pass the desks of the Brazilian censors without problems ${ }^{36}$. The Brazilians, in turn, requested documentaries and movies with historical themes, which were supposed to be an entertaining as well as didactically valuable means for constructing the country's history:

\footnotetext{
${ }^{35}$ See Motion Picture Society for the Americas (NARA II, RG 229, Office of Inter-American Affairs, General Records, Central Files, Group 3, Information, Box 961).

${ }_{36}$ Memorandum by Berent Friele and Frank Nattier, September 1, 1941 (NARA II, RG 229, Office of Inter-American Affairs, Coordination Committee for Brazil, Box 1283).
} 
"What would please us most would be pictures produced on Brazilian subjects, either in the United States or in Brazil, with American stars and, whenever possible, with the addition of some Brazilian elements. The principal source to explore, in this field, would be episodes with respect to our history, like, for example the epopoeia of the Bandeirantes (pioneers), the episodes of the Indian civilization by the Jesuits, the independence wars (like the Inconfidencia Mineira), the episodes of the court of D. João VI and $D$. Pedro II, which give a relief of the national Brazilian spirit. ${ }^{, 37}$

Their wishes reflect very well the themes they considered important for the construction of the past in the Estado Novo's nation building process. Moreover, such films, especially if produced in the United States, would help to publicize Brazil and its long history and culture abroad. For the transfer of technical know-how, the Estado Novo compromised with the Americans, who insisted that such aid would only feasible if existing regulations protecting the domestic film industry (by stipulating a certain number of Brazilian films to be shown per week in movie theaters) were loosened in favor of the American film industry ${ }^{38}$.

The idea of inviting Orson Welles for a film about Brazil and the carnival also originated in the DIP and its director Lourival Fontes ${ }^{39}$. Welles' project It's All True was an effort to capture the purported unvarnished reality instead of harmless and picturesque carnival scenes. He thereby not only irritated his producers in Hollywood, who actually dropped the project claiming exploding costs, but enraged his political patrons in Brazil. The latter wanted him to capture colonial and modern Rio, its beaches and leisure activities, not the dark-skinned poor from the favelas. They expected him to produce tourist images that would enhance Brazil's image among both domestic and foreign audiences. As such, this episode shows how the cultural

\footnotetext{
${ }^{37}$ Departamento de Imprensa e Propaganda to John Hay Whitney, September 1, 1941 (NARA II, RG 229, Office of Inter-American Affairs, Coordination Committee for Brazil, Box 1283).

${ }^{38}$ Memorandum by Berent Friele and Frank Nattier, September 2, 1941; John Hay Whitney to Lourival Fontes, August 29, 1941 (NARA II, RG 229, Office of Inter-American Affairs, Coordination Committee for Brazil, Box 1283, Motion Pictures).

${ }^{39}$ Several studies on the Vargas regime and the U.S.-Brazilian alliance suggest that Fontes, like the police president Filinto Müller and Attorney General Francisco Campos, had to leave the political stage, because their sympathy for the Axis was not compatible with the foreign political shift toward the United States. In the case of Fontes, this does not seem to be true. Fontes was eager to collaborate with the U.S. institutions from the beginning. A local reporter of Rockefeller's Bureau for Latin American Research wrote to the Washington Headquarters of the OIAA, how astonished the OIAA people were to see Fontes dismissed from his job in 1942 - despite his helpful cooperation. The reporter felt the army to demand a stronger influence in the DIP. Fontes' successor was an army officer. Confidential Reports from Brazil, No. 9, May 21,1941 (NARA II, RG 229, Office of InterAmerican Affairs, Coordination Committee for Brazil, Box 1341, Folder 52.3). See also Brazilian Division to the OIAA, July 21,1942 (NARA II, RG 229, Office of Inter-American Affairs, General Records, Central Files, Group 4, Administration, Box 313, Folder Radio, Misc.).
} 
and economic interests of the white Brazilian elite and profit-orientated Hollywoodproducers overlapped. Yet, if Welles' film camera subverted the ambitions of Brazil's elites and Hollywood moguls, in other respects he seems to have satisfied the expectations of both the OIAA and the Estado Novo. He gave lectures and interviews and crowned President Vargas' birthday party as a special guest in one of Rios luxurious casinos. All in all, the Brazilian press and public appreciated Welles' efforts to understand country, culture and people. They favorably compared Welles with other "goodwill ambassadors" mobilized by the OIAA, including actors Tyrone Power and Douglas Fairbanks Jr. as well as the crooner Bing Crosby. On his return to the U.S.A., Welles made Brazil a prominent topic in his radio show Hello Americans, trying to sensitize audiences and to eradicate stereotypes: "Don't think that the function of Brazilian music is to translate American hits into Portuguese", or that "Brazilians do nothing but Samba"40.

What Orson Welles' It's All True was unable or unwilling to supply, Walt Disney was able to do with the much cited production Saludos Amigos (1942/43), that was ordered by the OIAA for Latin American as well as U.S.-American audiences, and ran in Brazil under the title Alô Amigos. The cultural encounter between Donald Duck and the Disney-invented Brazilian parrot Joe "Zé" Carioca in the film sequence Aquarela do Brasil can be read and interpreted in two ways: On the surface, Zé Carioca, the fast-speaking, cigar-smoking, umbrella-toting parrot seems to present the more remarkable creature, as he has a good command of English and weathers the cultural encounter very well, while the befuddled Donald Duck desperately thumbs through Portuguese dictionaries as he does not understand his South American neighbor's exuberant words of welcome. Yet, a more fitting interpretation points into a different direction. Donald Duck really does not need to learn any Portuguese because he is accompanied by a talented, native tour guide, who takes him by the hand and shows him the tourist attractions of the capital: the beautiful Guanabara Bay with the Sugar Loaf, cachaça, samba and casinos. The samba Aquarela do Brasil ranked first in the U.S.-Charts in February 1943. Cartoon figures inhabit a world beyond materiality, cartoons can also be the site of unbridled

\footnotetext{
${ }^{40}$ See Stam, Robert (1997). Tropical Multiculturalism. A Comparative history of Race in Brazilian Cinema and Culture, Durham, NC and London: Duke University Press, p. 115.
} 
expressions of the individual and collective unconscious ${ }^{41}$. For the OIAA's Brazilian Division, Disney's mélange of documentary and comic fulfilled the bilateral needs for tourist images and pan-American harmony even better than Stefan Zweig's homage to his tropical exile, Brazil. Land of the Future ${ }^{42}$. Disney's Saludos Amigos as well as his other feature film The Three Caballeros, the first color feature that combined live action with animation, fulfilled expectations of the "authentic exotic" and erotic "other", of Latin America as a "surprise package" that could be tasted during a well organized tourist tour in the unknown territory south of the Rio Grande. In terms of culture transfer, Brazilian films did not have a chance to conquer the American market. The only film was $O$ Brasileiro João de Souza, a propagandistic melodrama, written by Adolfo Chust about the Brazilian contribution in the war against the German threat ${ }^{43}$.

Apart from movies and documentary films, the OIAA also looked toward radio as a vehicle to reach and influence audiences in Brazil. It engaged Princeton University public opinion researchers Hadley Cantril and Lloyd A. Free to investigate the tastes and preferences of radio listeners, as well as the quality of transmissions and the influence of Axis stations ${ }^{44}$. It greatly expanded the volume of Portuguese language programs short-waved from the United States ${ }^{45}$, and it set out to find ways and means by which to gain access to domestic stations that would greatly increase the size of audiences exposed to U.S. programming.

In Brazil, as in other Latin American countries, radio was the most important means of communication. Radio reached all parts of the country and did not require knowledge of reading. Not surprisingly, it became heavily regulated by the DIP. In the Estado Novo, radio was seen as an important vehicle for the construction of a national identity (brasilidade), and the DIP restricted access to this mass medium.

${ }^{41}$ Burton, Julianne (1992). "Don (Juanito) Duck and the Imperial-Patriarchal Unconscious: Disney Studios, the Good Neighbor Policy, and the Packaging of Latin America". In: Parker, Andrew (ed.) et al. Nationalisms and Sexualities, New York and London: Routledge, p. 31.

${ }_{42}$ The film was shown in six theaters at the same time and received good critiques: "The public laughed with gratitude. The character of the Brazilian parrot remained in everybody's mind as an invention inspired by the friendship of the North for the South. Films like that of Walt Disney make the Brazilians forget North American paternalism." Report from December 23, 1942 (NARA II, RG 229, Office of Inter-American Affairs, General Records, Central Files, Group 3, Information, Motion Pictures, Box 227, Folder Reports). The parrot survived in Brazilian Disney-magazines as character.

${ }^{43}$ Adolfo Chust, João de Souza, Drama (Biblioteca Nacional, Rio de Janeiro, DIP: Divisão de Cinema e Teatro, October 3, 1942).

44 Hadley Cantril, "A survey of Communications in Brazil. Confidential Report", American Social Surveys, Inc. Princeton, New Jersey (NARA, RG 229, Office of Inter-American Affairs, General Records, Central Files, Group 4, Administration, Box 318).

${ }^{45}$ On the volume of short-wave broadcasting see Ogilvie, John W. G. (1945) "The Potentialities of Inter-American Radio". In: Public Opinion Quarterly 9:1, pp. 19-28. 
Such restrictions also applied to the wartime ally, the United States. Whereas in other parts of Latin America during the war years many radio stations hooked up with U.S. networks such as CBS and NBC to retransmit programs from the United States ${ }^{46}$. State regulations in Brazil blocked such rebroadcast arrangements. Hence, the OIAA faced considerable hurdles when it tried to have Brazilian stations broadcast programs produced by its Radio Division.

If the OIAA at last did achieve a modicum of success this was largely due to the negotiating ability of Berent Friele. The OIAA gained the right to supply five minutes of the state-run news hour, Hora do Brasil, broadcast daily between 7:00 and 8:00 p.m. The OIAA was also allowed to provide a further broadcast from New York for the following fifteen-minute timeslot. This show, Calling Brazil, informed its U.S.American listeners about psychological warfare, war sacrifices, about facts and figures, landscape beauties and mentalities of Brazil. The Estado Novo's cooperation, however, came at a price. The OIAA's Radio Division had to open its doors to Brazilian censorship officials. Thus, Calling Brazil was actually produced by Julio Barata, the former head of the DIP's Radio Division, who had been hired by the OIAA for this purpose. To take on Barata and Fontes, high-ranking censorship officials who continued to respond to orders from a dictatorship, and make Barata a paid official of a government that professed to defend democracy and liberalism, was a rather exceptional move on the part of the OIAA, but it evidences to the ideological flexibility on both sides of the U.S.-Brazilian wartime alliance. It also demonstrates the ability of the Vargas regime to dictate the terms of cooperation. The presence of Brazilian censorship officials within the OIAA's Radio Division thus allowed the Rockefeller agency to gain access to radio stations in Brazil for limited retransmission purposes and to draw on the expertise of Brazilians who had a better understanding of the sensibilities and preferences of audiences targeted by these programs.

Apart from political news and informational programs, the OIAA also produced quizzes for children, political round tables and radio plays to be rebroadcast by Brazilian stations. The comedy Barão Eixo, for example, depicted a dupe with a pronounced German accent, who believes and reproduces the propaganda spread by Radio Berlin, but is permanently challenged by an alert boy whose pointed questions debunk the German news and bring the Baron into argumentative troubles. Barão Eixo thus had radio audiences witness conversations about the doubtful

\footnotetext{
${ }^{46}$ Such retransmission arrangements are discussed in Gisela Cramer's contribution to this volume.
} 
quality of Axis propaganda. As Barón Eje, this theatrical play was also broadcast in Spanish-America, but the Portuguese version was adapted to particular Brazilian conditions. Thus, in view of the considerable Japanese minority in Brazil, in this version the Baron is accompanied by an obsequious Japanese named Fujita, who always agrees with his master, while talking politics with a woman named Dona Marculinas, to whom he reports news from Berlin ${ }^{47}$. Whether or not this or other programs fulfilled their objectives is impossible to ascertain, but it is important to note that they would find their way to Brazilian stations only after the DIP had given the Estado Novo's official blessing.

By comparison, the OIAA's exchange programs for artists and intellectuals seem to have produced longer-lasting results. When the Brazilian muralist Cândido Portinari was hired to create a four part painting cycle for the Hispanic Division of the Library of Congress, George Biddle, the brother of U.S. Attorney General Francis Biddle and fellow muralist, traveled to Rio de Janeiro in exchange. There, he created two frescos depicting the war in the National Library, where they remain until this day $^{48}$. The OIAA achieved similarly long-lasting effects by giving a scholarship to Erico Veríssimo. This Brazilian, who is until now known only as a writer ${ }^{49}$, was in fact one of the most important literary agents mediating between the two nations. With the help of the OIAA, Veríssimo moved to the U.S., where he engaged in true speaking marathons about Brazil, in addition to teaching at Berkeley during 1943. He returned to the U.S. in 1952 as Secretary General of the Cultural Section of the OAS. As the agent for the Brazilian publishing house Livraria Globo in the thirties, he had made American literature known in Brazil and advised U.S. publishers. While working for the OIAA in 1943, he wrote O Gato Branco em Campo de Neve (Black Cat on a Field of Snow) that soon became a bestseller in Brazil. As the OIAA had hoped, the young author set out to provide Brazilians with a strong, cheerful image of the United

\footnotetext{
${ }^{47}$ Brazilian Division to the OIAA, January 7,1942; Berent Friele to Jefferson Caffery, February 2,1941 (NARA II, RG 229, Office of Inter-American Affairs, Coordination Committee for Brazil, Box 1301, Folder 05.4.1); for Calling Brazil see Box 1300, Folder 05.4.

${ }^{48}$ Archibald MacLeish to Getúlio Vargas, September 17,1941 (Fundação Getúlio Vargas, CPDOC, papers of Gustavo Capanema, rolo 5, 683; see also NARA II, RG 229, Office of Inter-American Affairs, Coordination Committee for Brazil, Box 1213; George Biddle, Diary/Dec.1941-Dec.1942, May 26,1942 (Library of Congress, Manuscript Division, papers of George Biddle, $0457 \mathrm{H}$, Box 28, Folder 2); Berent Friele to the OIAA, February 10,1942 (NARA II, RG 229, Office of Inter-American Affairs, Coordination Committee for Brazil, Box 1324, Folder 06.11).

${ }^{49}$ In 1935 he published Caminhos Cruzados [Crossroads, 1943], 1938 Olhai os lirios do Campo was published [Consider the Lilies in the Field, 1947]
} 
States ${ }^{50}$. However, his book, peppered with key words like Kodak, Coca-Cola, swing, and cowboy, was not an uncritical homage to the great nation in the north. Well aware of his informed and critical readership in Brazil, Veríssimo depicted, for example, a stroll through a slum in Washington and he denounced U.S. apartheid. He thus implicitly distanced himself from the position on race as maintained by the OIAA, a discourse that did not deny discrimination but tended to stress America's capacity to change toward the better. Rather, Verissimo's position reflected a Brazilian discourse on race, a discourse that was now reaching dominance as the myth of racial democracy.

\section{Consequences of the War Time Alliance}

The consequences of the economic influence of U.S. institutions and enterprises upon Brazil as well as the intense culture policy and propaganda provoked much criticism in Brazil. In late 1942 the painter George Biddle was told by the journalist Samuel Wainer, that most Brazilians believed their country to be transformed in a U.S.-American colony ${ }^{51}$. In 1944, Mauricio de Medeiros deplored the CocaColaization of Brazil in the Diario Carioca, denouncing the massive physical and cultural presence of the Americans ${ }^{52}$. The Brazilian modernista and writer Oswald de Andrade heavily criticized the concept of racial segregation in the U.S. South as an example of U.S.-American mendacity. With analytical precision he deplored U.S.capitalism as marked by Puritanism, and he faulted the racist upper and middle classes for condemning the southern states of the United States to rural poverty, suggesting that Panamericanism was about to do the same to Latin America, by trampling upon the politics of the New Deal and Franklin D. Roosevelt's humanitarism ${ }^{53}$.

The wartime alliance brought about a massive increase of economic interchange between both countries. In 1940 Brazil had imported goods valued at $\$ 111$ million from the United States; five years later the value of imported goods had risen to $\$ 210$ million. At the same time Brazil was able to triple its exports to the

\footnotetext{
${ }^{50}$ Correspondence of Erico Verissimo (Arquivo Literario Érico Veríssimo, ALEV, Porto Alegre). See Verissimo, Erico (1941). Gato Preto em Campo de Neve, Porto Alegre: Globo.

${ }^{51}$ George Biddle, Diary Dec. 1941-Dec.1942, October 31,1942 and November 1,1942 (Library of Congress, Manuscript Division, papers of George Biddle, $0457 \mathrm{H}$, Box 28, Folder 2).

${ }_{52}$ Medeiros, Mauricio de. "Ghettos para Negros". In: Diario Carioca, 9.5.1944.

${ }^{53}$ Andrade, Oswald de. "Aqui foi o sul que venceu". In: O Estado de São Paulo, 2.9.1943.
} 
United States from $\$ 105$ million in 1940 to $\$ 311$ million in $1944^{54}$. Between 1942 and 1945, the South American state received 73 per cent of all loans granted to Latin America by the United States ${ }^{55}$.

After the "brief honeymoon of U.S.-Brazilian relations between August 1942 and mid-1943", as Berent Friele had stated in his letter to Nelson Rockefeller ${ }^{56}$, however, the impact of war and the wartime alliance brought about frictions that were difficult to contain, and even harder to explain away by propaganda, mostly so in those regions which experienced them at first hand. Prices for raw materials, household goods, and U.S.-imports rose steadily in Brazil until 1943; wheat and white sugar were rationed, an alternative fuel made out of lumber, called gasogênio, was produced and served as one symbol of national unity and war sacrifice on the home front. Advertisements tried to boost the ugly container that adorned cars by stressing the comfort of the interior ${ }^{57}$. Farmers were not able to buy wire to repair the fences of their farms. In 1945, public transport and construction works had almost broken down, except for the luxurious hotel Quitandinha in the mountains near Rio de Janeiro that would be opened two years later ${ }^{58}$. Expensive consumer goods were only affordable for the small upper and middle class. Lux soap, U.S. films, and lectures by U.S. intellectuals contrasted sharply with arrogant U.S. engineers in the Amazon, sometimes vulgar-mouthed Marines in Brazilian coastal towns and with scarcity of important primary goods and foodstuff.

The Brazilian Division sought to respond to these economic consequences, especially after mid-1943, where Germany's defeat loomed on the horizon. Berent Friele advocated that the OIAA turn toward a consolidation of the achieved goals and their defense in the post-war period ${ }^{59}$. The particular makeup of the OIAA and its regional offices was also bound to provoke or reinforce suspicions. Rockefeller was associated with Standard Oil and Berent Friele, the former manager of the American Coffee Corporation and director of the OIAA's Brazilian Division, was likewise

\footnotetext{
${ }^{54}$ Gambini, Roberto (1977). Op. Cit., p. 94.

${ }^{55}$ Weis, Michael W. (1993). Cold Warriors and Coups d'etat. Brazilian-American Relations, 19451964, Albuquerque NM: University of New Mexico, p. 11.

${ }^{56}$ Berent Friele to Nelson A. Rockefeller, August, 23, 1943 (NARA II, RG 229, Office of Inter-American Affairs, General Records, Central Files, Group 4, Administration, Box 443, Folder Berent Friele).

${ }^{57}$ Cytrynowicz, Roney (2000). Op. Cit.

${ }^{58}$ Sá, Hernane Tavares de (1947). The Brazilians. People of Tomorrow, New York: J.Day Co, p. 18. Tavares de Sá was until 1944 adviser of the OIAA. See RAC, RFA, NAR III 4

L, OIAA, Box 239, Folder 2398.

${ }^{59}$ Berent Friele to Nelson Rockefeller, August 28, 1943. (NARA II, RG 229, General Records, Central Files, Group 4, Administration, Box 443, Folder Berent Friele).
} 
associated with Big Business. More than a few Brazilians therefore viewed the Brazilian Division as a center of U.S.-imperialism, especially in times of the crisis.

Thus, from mid-1943 onwards the contents of OIAA media production devised in Washington concentrated on explaining to the people south of the Rio Grande how perfectly the U.S. American civil society coped with fulfilling the duty of war sacrifice. Thus an internal memorandum of the OIAA stressed:

"We must make the people know what sacrifices the American people are making - no servants, poor laundry and other personal services, homes broken, transportation hardships, etc. The sacrifice theme must be brought out. ${ }^{, 60}$

At the same time, the Brazilian Division had to defend the goals of economic sustainability beyond the war and its own survival, but had more and more troubles to save the loosing image.

\begin{abstract}
"As the postwar transition develops, there can be expected to be a considerable amount of criticism, blame and complaint. [...] Since the Americans are almost the only foreigners who have been active here for many months now, most of the blame for the difficulties and problems of any character can be expected to be placed on the United States. Our enemies will certainly be more active than ever in taking advantage of the situation. ${ }^{1,61}$
\end{abstract}

The military cooperation with the United States enabled Brazil to become the leading military power in Latin America. The construction of the steel plant Volta Redonda, the flagship of Brazilian modernization, through the United States, fostered industrialization and the transformation from an agricultural state to a modern, diversified nation ${ }^{62}$. Parallel to the increase of the trade relations between the two countries and despite of the strong presence of U.S. organizations on Brazilian ground, the South American state successfully pushed its politics of nationalization ahead: while the majority of banks in 1938 were in foreign hands, their number among the ten largest banks in 1947 was reduced to two ${ }^{63}$.

Volta Redonda, because it had been built almost exclusively by the Northern partner, was an example of how Brazil skillfully integrated diverse results of the

\footnotetext{
${ }^{60}$ Meeting, November 17, 1943 (NARA II, RG 229, Office of Inter-American Affairs, Coordination Committee for Brazil, Box 1266, Folder 02.13).

${ }^{61}$ Berent Friele to Nelson A. Rockefeller, August 23, 1943, (NARA II, RG 229, Office of Inter-American Affairs, Coordination Committee for Brazil, Box 1261, Personal, BD-1244).

62 Leopoldi, Maria Antonieta (1999). "Estratégias de ação empresarial em conjunturas de mudança política”. In: Pandolfi, Dulce (ed). Repensando o Estado Novo, Rio de Janeiro: Editora FGV, p. 123.

${ }^{63}$ Leopoldi, Maria Antonieta (1999). Op. Cit., p. 127.
} 
wartime alliance in its nation-building-process, although Vargas stressed the merits of the United States: "An imperialist policy does not aid its neighbors to create a steel industry - yet Volta Redonda has only been possible through the aid of the United States", he declared in a speech at the fifth anniversary of the Estado Novo ${ }^{64}$. Volta Redonda was made the flagship of Brazilian industrialization by the DIP, its steel workers were depicted as the role model for the new working class. Perfect working conditions, homes, leisure time facilities - Volta Redonda had its own soccer team demonstrated the modern Brazilian worker and his corporate identity ${ }^{65}$. After the war, Volta Redonda was depicted as an example of Brazil's industrial expertise and was "sold" as a genuine Brazilian technical achievement.

The Vargas regime even took the scarcity of goods after mid-1943 to demonstrate national unity. Dieticians in the employ of the Estado Novo endeavored to propagate the switch from white bread to corn products as progress in public health. Even until 1944 São Paulo so called blecautes, regular blackout exercises, were organized and remained being the most commemorative elements of the Brazilian home front for many civilians ${ }^{66}$.

The DIP also sought to depict the alliance as one of equal partners, even as the terms of interaction were very much dependent on the interests and preferences of the stronger partner, the United States. The Brazilian propaganda machinery went even further than demonstrating equal strength and achievements in the "democratic fight" against European fascism. It proposed that Brazil's cultural capacity of ethnic integration was much more democratic than that of its wartime partner. It referred to apartheid and racial segregation in the U.S. South in order to present Brazil as a model society that had achieved perfect and peaceful coexistence of different ethnic groups, a true "racial democracy", which the Vargas regime also sought to export. Chlodomir Vianna Moog, who was one of the candidates to be invited to the United States with a scholarship, wrote in the New York Herald Tribune: "If I were asked to name the most important or most significant aspect of Brazilian civilization, I should say without hesitation the complete absence of racial problems. ${ }^{67}$ If this propaganda

\footnotetext{
${ }^{64}$ Speech by Getúlio Vargas at the 5th anniversary of the Estado Novo (NARA II, RG 229, Office of Inter-American Affairs, Coordination Committee for Brazil, Box 1304, Folder 05.6, 2).

${ }_{65}$ Mayrink Veiga, Fonseca, Volta Redonda, 18. See Speech by Vargas (NARA II, RG 229, Coordination Committee for Brazil, Box 1304, Folder 05.6, 2).

${ }^{66}$ Cytrynowicz, Roney (2000). Op. Cit. pp. 104, 122.

${ }^{67}$ Moog, Vianna. „Race Problems Are Lacking in Life of Brazil“, September 12, 1943 (NARA II, RG 229, Coordination Committee for Brazil, Box 1318, Vianna Moog).
} 
machinery had started out using the mass media in order to instill a sense of homogenous, national identity in a vast and heterogeneous state, this sense of brasilidade, would ultimately provide the basis for the construction of a counterculture against strong U.S.-American influence. Thus, if the OIAA and the wartime alliance exerted a strong influence on Brazil, they did not "Americanize" the country.

The cooperation with the United States should have strengthened the Estado Novo's hold on the public domain. In this sense, some scholars and contemporary critics have argued that the United States helped Getúlio Vargas to stay in power ${ }^{68}$. True, there are good reasons to assume that Vargas and other protagonists benefited from the wartime alliance. Yet, at the same time, the actual propagandistic contents disseminated by both the DIP and the OIAA, may well have served to undermine the regime's legitimacy. Both agencies stressed the topic of the two democracies fighting against totalitarian powers, a discourse that could not but manifest a glaring contradiction. For those quarters of Brazilian society increasingly dissatisfied with the dictatorial regime, such a discourse served to strengthen the resolve to bring about a regime change. One part of the clandestine student opposition focused especially on the relationship with an imperialist power. Other student groups, Paulista politicians, the University of São Paulo, former state governors who had been dismissed from their offices with the coup d'etat 1937, and democratic Brazilian citizens hoped that the democratic influence, transported by the U.S. culture policy, would contribute to a political transition ${ }^{69}$. The pro-American Brazilian foreign minister Oswaldo Aranha, co-founder of the anti-Vargas Sociedade Amigos da América, criticized not only the persistence of fascist leanings within the military, but also Vargas' refusal to held elections and to reestablish democracy ${ }^{70}$. Criticism was often focused on the question, why the Vargas administration did not

\footnotetext{
${ }^{68}$ AMA 41.08.06 (Fundação Getúlio Vargas, CPDOC, Agencias Militares do EUA).

${ }^{69}$ Moe Berg to Nelson A. Rockefeller, February 27, 1943 (RAC, RFA, NAR pers. III 4 0, OIAA, Box 4 , Moe Berg Mission). See Moura, Gerson (1982). Brazilian Foreign Relations 1939-1950. The Changing Nature of Brazil-United States Relations during and after the Second World War, Op. Cit., p. 152. The state of São Paulo in 1932 had organized a revolution against the Vargas regime. The University of São Paulo was influenced by many of its European teachers, most of them Nazi refugees, by U.S. American scholars and by politically liberal teachers and students.

70 See Reabertura da "Sociedade Amigos da América" em 20.4.1945. Discursos pronunciados pelos Senhores General Manoel Rabelo e Dr. Oswaldo Aranha, o O. 1945. See Dulles, John F. (1984). A Faculdade de Direito de São Paulo e a Resistência Anti-Vargas 1939-1945, Rio de Janeiro: Nova Fronteira/EDUSP.
} 
invest the profit from this wartime alliance in social and educational programs, but built casinos and provided its clientele with privileges ${ }^{71}$.

\section{Concluding Remarks}

The Brazilian example serves on one hand to illustrate the intertwining of economy, politics, and culture in the structure of Nelson A. Rockefeller's Office of InterAmerican Affairs; on the other hand its serves to describe the reactions, strategies of accommodation and resistance of the largest South American state against the U.S.influence. As this chapter shows, the OIAA intended to ease the transition of Brazil into the wartime alliance, by mitigating negative externalities and by convincing the Brazilian public to accept the burdens of bilateral cooperation in the war effort. In this endeavor, however, the OIAA was not the only relevant actor. It faced state institutions that followed their own agenda, often compatible if not entirely congruent with U.S. foreign policies.

The OIAA often was in its own way. The agency undoubtedly commited numerous mistakes, which were often the result of "false assumptions" and of a lack of knowledge. After Regional Committees were established, in 1942, the central offices of the OIAA began to receive more regular and useful information from its local offices as well as from questionnaires and public opinion studies. The areas of competence of the Brazilian Division, however, changed over time as other wartime agencies came to assume various of its functions, particularly in fields related to blacklisting and the requirements of the war economy. From late 1942 until 1945, the Division's main field of action was public diplomacy.

The businessmen hired by the OIAA did not only work in the economic, but also in the culture field and they were sometimes at odds with the more idealistic cultural ambassadors, such as musicologist Carleton Sprague Smith and the film director Orson Welles. Representatives of the U.S.-movie industry, who acted at the same time as culture politicians viewed culture also as a product to be sold and the media and films as another market to be conquered by the United States.

The cultural products aimed at creating a broad understanding about the U.S. wartime needs, at legitimizing the war economy and at deconstructing stereotypes of

\footnotetext{
${ }^{71}$ See report from Horace Peterson, July 11, 1944 (NARA II, RG 226, Office of Strategic Services, Box 980, №. 84283, Military Intelligence Division).
} 
the United States in Brazil through the production of new images. The cultural and academic policy of the U.S., which strove for "other images" of the U.S., was successful in portions of the middle and upper class and made it possible for Brazilian and U.S.-scholarship recipients such as Erico Verissimo to expand their horizons and make careers.

The negative consequences of the war economy, such as the increased scarcity of goods and the inflationary pressures, were not predictable in the first two years of the agency's activities. The media production, which was consumer good and ideological vehicle at the same time, led to overstressed messages, that reproduced the "old images" many Latin Americans had about the North. These information campaigns of repetitive slogans and messages made the OIAA into a propaganda bureau for U.S. foreign policy in Latin America, although some staff members of the State Departments and critical intellectuals were aware of the ambivalence of information and culture strategies.

Several Brazilian politicians and businessmen profited from the culture and economic transfer, and the political opposition in Brazil was partly supported. The Brazilian government was able to achieve advantages in this "power play". The steel plant Volta Redonda, although it had been built almost exlcusively by the Northern partner, was an example of how Brazil skillfully integrated diverse results of the wartime alliance in its nation-building-process.

The Brazilian Press and Propaganda Department (DIP) was the most important cooperation partner of the OIAA in the field of public diplomacy. The cooperation manifested in hiring Julio Barata for the OIAA radio show Calling Brazil in New York and in founding Orson Welles' film experiment It's all true. The DIP was firstly able to profit from the technical imports from the United States. Its culture production was secondly used to blur the real power relations in this wartime alliance and made Brazil propagandistically the more powerful partner. Thirdly the culture politics - apart from its identity function - was used for the construction of a counterculture against the strong U.S.-American influence. It emphasized the Brazilian achievement of a multi-ethnic society free from conflicts, a "true" racial democracy formed by the people - in constrast to the segregated society in a nation which was proud of its democratic and liberal tradition, that tried to spread this exceptionalism through a global civilizing mission (although this Brazilian racial democracy was a myth and continues to be one). But the DIP was also able to direct the distribution of 
U.S.-american cultural products through its censorship politics. State regulations blocked U.S. rebroadcast arrangements.

Although it was founded as a war organization, the OIAA - from the beginning - aimed at the implementation of its interests on a long-range basis, in order to hamper European influence after the war. The public diplomacy of the OIAA did not have the lasting positive influence intended, mostly because the Cold War introduced a new era in diplomatic relations. Bilateral cooperation, which was established during the war years by OIAA members affiliated to U.S. corporations continued to prosper without governmental support or control after the war. Nelson Rockefeller's American International Association for Economic Development (AIA) and International Basic Economy Corporation (IBEC), both established in 1946, carried the networks in the field of agribusiness on and expanded them, partly with the same staff.

\section{Bibliographical References:}

Abreu, Marcelo (1999). O Brasil e a economia mundial 1930-1945, Rio de Janeiro: Civilização Brasileira.

Araujo, Ricardo Benzaquen de (1986). "O Dono da Casa. Notas sobre a imagem do poder no 'mito Vargas'”. In: Religião e Sociedade,13/2, pp. 102-122.

Bandeira, Luiz Alberto Moniz (1973). Presença dos Estado Unidos no Brasil, Rio de Janeiro: Ed. Civilização Brasileira.

Bastos, Nilo Chaves de Brito (1996). SESP-FSESP. Evolução Histórica 1942-1991, Brasilia: Fundação Nacional de Saude.

Burton, Julianne (1992). "Don (Juanito) Duck and the Imperial-Patriarchal Unconscious: Disney Studios, the Good Neighbor Policy, and the Packaging of Latin America". In: Parker, Andrew (ed.) et al. Nationalisms and Sexualities, New York and London: Routledge. 
Campos, André Luiz Vieira de (1997). International Health Policies in Brazil: The Serviço Especial de Saúde Pública, 1942-1960, Unpublished PhD Diss. The University of Texas at Austin.

Capelato, Maria Helena (1998). Multidões em Cena. Propaganda Política no Varguismo e no Peronismo, São Paulo: Papirus.

Carneiro, Maria Luiza Tucci (1999). "O Estado Novo, o Dops e a ideologia da segurança nacional”. In: Pandolfi, Dulce (ed.). Repensando o Estado Novo, Rio de Janeiro: Editora FGV, 1999, pp. 327-340.

Cobbs, Elizabeth Anne (1992) The rich Neighbor Policy. Rockefeller and Kaiser in Brazil, New Haven, London: Yale University Press.

Cytrynowicz, Roney (2000). Guerra sem Guerra. A mobilização e o cotidiano em São Paulo durante a Segunda Guerra Mundial, São Paulo: EDUSP.

Dulles, John F. (1984). A Faculdade de Direito de São Paulo e a Resistência AntiVargas 1939-1945, Rio de Janeiro: Nova Fronteira/EDUSP.

Dulles, John F.W. (1967). Vargas of Brazil, London, Austin: Texas University Press.

Faoro, Raymundo (1977). Os Donos do Poder. Formação do Patronato Político Brasileiro, Porto Alegre: Globo.

Gambini, Roberto (1977). O Duplo Jogo de Getúlio Vargas. Influência Americana e Alemã no Estado Novo, São Paulo: Edições Símbolo.

Garfield, Seth (1997). "The Roots of a Plant that Today is Brazill: Indians and the Nation-State under the Brazilian Estado Novo". In: Journal of Latin American Studies 29.

Gellman, Irwin F. (1979) Good Neighbor Diplomacy. United States Policies in Latin America 1933-1945, Baltimore, London: The Johns-Hopkins University Press. 
Goulart, Silvana (1990). Sob a verdade oficial. Ideologia, propaganda e censura no Estado Novo, São Paulo: Marco Zero Editora.

Hentschke, Jens (2006). Vargas and Brazil. New Perspectives, New York: Palgrave, Macmillan.

Hentschke, Jens (1996) Estado Novo. Genesis und Konsolidierung der brasilianischen Diktatur von 1937, Saarbrücken: Verlag für Entwicklungspolitik.

Huggins, Martha K. (1989) Political Policing. The United States and Latin America, Durham, London: Duke University Press.

Kraus, Louise Theresa (1986). The Establishment of United States Army Air Corps Bases in Brazil, 1938-1945, Unpublished PhD Diss. College Park: University of Maryland.

Kirsch, Thomas (1977). Die Entwicklung der argentinischen Filmindustrie, Münster: MAks Publikationen.

Leopoldi, Maria Antonieta (1999). "Estratégias de ação empresarial em conjunturas de mudança política". In: Pandolfi, Dulce (ed). Repensando o Estado Novo, Rio de Janeiro: Editora FGV.

Mallimacci, Fortunato and Marrone, Irene (1977). Cine e imaginário social, Buenos Aires: Facultad de Ciencias Sociales.

Marinho, Maria Gabriela (2001) Norteamericanos no Brasil. Uma história da Fundação Rockefeller na Universidade de São Paulo (1934-1952), São Paulo: Coleção Educação Contemporânea.

McCann, Frank D. (1973). The Brazilian-American Alliance 1937-1945, Princeton: Princeton University Press. 
Miceli, Sergio (1990) A desilusão americana. Relações acadêmicas entre Brasil e Estados Unidos, São Paulo : IDES/Editora Sumaré.

Moura, Gerson (1984). Tio Sam chega ao Brasil. A penetração cultural americana, São Paulo: Brasiliense.

Moura, Gerson (1982). Brazilian Foreign Relations 1939-1950. The Changing Nature of Brazil-United States Relations during and after the Second World War, Unpublished PhD. Diss., London.

Ogilvie, John W. G. (1945) "The Potentialities of Inter-American Radio". In: Public Opinion Quarterly 9:1, pp. 19-28.

Prutsch, Ursula (2008). Creating Good Neighbors? Die Kultur- und Wirtschaftspolitik der U.S.A in Lateinamerika, 1940-1946, Stuttgart: Franz Steiner Verlag.

Rady, Donald Edmund (1973). Volta Redonda, Albuquerque, New Mexico: Rio Grande Publishing Company.

Rocha, Denise (1998). "Sportethos und Monumentalismus - Tropischer way of life: die brasilianische Wahrnehmung des NS-Reiches und der U.S.A". In: König, HansJoachim and Rinke, Stefan (ed.). Transatlantische Perzeptionen: LateinamerikaU.S.A-Europa in Geschichte und Gegenwart, Stuttgart: Verlag Hans-Dieter Heinz and Akademischer Verlag, pp. 259-282.

Sá, Hernane Tavares de (1947). The Brazilians. People of Tomorrow, New York: J.Day Co.

Schwartzman, Simon et. al. (1984), Tempos de Capanema, São Paulo: Paz e Terra.

Souza, José Ignacio de Melo (1990). Ação e Imaginario de uma ditadura: Controle, Coerção e Propaganda Política nos Meios de Comunicação durante o Estado Novo, unpublished $\mathrm{PhD}$ diss. São Paulo. 
Stam, Robert (1997). Tropical Multiculturalism. A Comparative history of Race in Brazilian Cinema and Culture, Durham, NC and London: Duke University Press.

Tota, Antonio Pedro (2000). O Imperialismo Sedutor. A Americanização do Brasil na Época da Segunda Guerra, São Paulo: Companhia das Letras.

Veiga, Sandra Mayrink and Fonseca, Isaque (1990). Volta Redonda, entre o aço e os armas, Petrópolis: Editora Vozes.

Verissimo, Erico (1941). Gato Preto em Campo de Neve, Porto Alegre: Globo.

Weis, Michael W. (1993). Cold Warriors and Coups d'etat. Brazilian-American Relations, 1945-1964, Albuquerque NM: University of New Mexico.

Williams, Daryle (2001). Culture Wars in Brazil. The First Vargas Regime, 19301945, Durham, London: Duke University Press.

Wirth, John D. (1970). Politics of Brazilian Development 1930-1954, Stanford, Ca: Stanford University Press.

\section{Email: ursula.prutsch@Irz.uni-muenchen.de}

Ursula Prutsch: Historian, Associate Prof. At the Amerika-Institute at the LudwigMaximilians-Universität Munich (Germany); publications on history of Latin America (esp. Brazil and Argentina), Inter-American Affairs and transatlantic migrations. 